\title{
SUPERVISI SEBAGAI PENINGKAT MUTU PENDIDIKAN \\ UNTUK MENCAPAI KUALITAS PENDIDIKAN INDONESIA
}

\author{
Sri Kurniawati \\ Srikurniawati207@gmail.com
}

\begin{abstract}
ABSTRAK
Supervisi pendidikan merupakan pembinaan yang berupa bimbingan kearah perbaikan dalam pendidikan pada umumnya dan peningkatan mutu mengajar dan belajar pada khususnya. Supervisi dilaksanakan oleh seorang supervisor. Supervisor bertanggung jawab dalam mengawasi jalannya pendidikan, membimbing dan membina guru untuk mengembangkan keterampilan dan kemampuan yang ada pada dirinya dalam mewujudkan pendidikan yang bermutu dan tercapainya tujuan pendidikan nasional. Dalam pelaksanaannya supervisi memiliki komponen-komponen antara lain, Pengumpulan data, penilaian, deteksi kelemahan, memperbaiki kelemahan, dan bimbingan dan pengembangan. Semua itu dilakukan agar pendidikan di Indonesia memiliki mutu yang tinggi sehingga mencapai kualitas pendidikan nasional.

Kata kunci : Supervisi pendidikan, Supervisor
\end{abstract}

\section{LATAR BELAKANG}

Supervisi pendidikan sering dilaksanakan berbeda dengan pengertian yang ada. Di mana sebagian supervisor mengartikan tugasnya sebagai pekerjaan yang sangat sederhana. Saat berada di lapangan dan mengunjungi kelas-kelas yang ada di sekolah, mereka mengamati guru yang sedang melaksanakan proses belajar mengajar kemudian mengisi instrumen yang dibawanya dan beranggapan bahwa sudah melaksanakan tugas sebagai supervisor.

Selain mengawasi dan mengisi instrumen seorang supervisor juga memiliki tanggung jawab membantu tenaga pendidik atau guru dalam menggali potensi dan meningkatkan kemampuan yang dimilikinya dalam proses belajar mengajar. Tercapai atau tidaknya suatu tujuan pendidikan dilihat dari tenaga pendidik atau yang sering kita sebut dengan seorang guru.

Diera milenial yang serba mengandalkan teknologi seperti ini hendaknya seorang pendidik dituntut untuk bisa menggunakan teknologi-teknologi yang mendukung berjalannya proses belajar mengajar. Namun, masih ada pendidik yang masih gagap dalam penggunaan teknologi. Selain gagap teknologi, tidak meratanya penyaluran fasilitas, sarana dan prasarana dalam proses belajar mengajar dapat mempengaruhi mutu pendidikan dalam mencapai tujuan pendidikan.

Hal ini yang dapat mempengaruhi pendidikan yang ada di Indonesia. Seorang pendidik dituntut untuk kreatif dan inofatif dalam menjalankan tugas agar proses 
belajar mengajar tetap berjalan dengan mestinya, meski sarana dan prasarana yang ada terbatas.

Untuk itulah peranan supervisi pendidikan harus di laksanakan bagaimana mestinya. Agar mutu dan tujuan pendidikan di Indonesia tercapai dengan maksimal dan kualitas pendidikan di Indonesia dapat bersaing dengan negara maju lainnya, dan mengurangi hal-hal yang dapat menurunkan mutu pendidikan Indonesia yang pada akhirnya melahirkan generasi-generasi penerus bangsa yang memiliki mutu yang kurang pula. Sehingga Indonesia di pandang rendah oleh negara lain.

Rumusan masalah dari artikel ini adalah (1) Apa itu supervisi pendidikan, (2)Apa peranan supervisi pendidikan, (3) Bagaimana pelaksanaan supervisi pendidikan.

Tujuan dari artikel ini (1)meningkatkan pemahaman tentang supervisi pendidikan, (2)mengetahui peranan supervisi pendidikan, dan (3)meningkatkan pemahaman tentang pelaksanaan supervisi pendidikan.

\section{PEMBAHASAN}

\section{A. Pengertian Supervisi Pendidikan}

Supervisi berasal dari bahasa inggris yaitu super dan vision. Super berarti diatas dan vision berarti melihat, dan masih serumpun dengan inspeksi, pemeriksaan dan pengawasan, dan penilaian dalam artian kegiatan yang dilakukan oleh orang yang berposisi atau kedudukan di atas (pemimpin) terhadap hal-hal yang ada di bawahnya.

Supervisi adalah pembinaan yang berupa bimbingan ke arah perbaikan dalam pendidikan pada umumnya dan peningkatan mutu mengajar dan belajar pada khususnya.

Secara etimologi, supervisi diambil dalam bahasa inggris "supervision" yang berarti pengawasan di bidang pendidikan. Orang yang menjalankan supervisi disebut dengan supervisor. (Mahful. 2015)

B. Peranan Supervisi Pendidikan

Menurut Rifai (1982) dalam syahril (2009 : 225-227) peranan supervisi pendidikan ada tujuh macam, antara lain :

1. Supervisi sebagai kepemimpinan

Supervisor sebagai pemimpin harus mempunyai kemampuan dalam mempengaruhi guru dalam meningkatkan kemampuan profesionalnya, sehingga proses belajar mengajar menjadi lebih baik dan efektif. Tanpa adanya kepemimpinan dari supervisor, kegiatan supervisi tidak akan efektif.

2. Supervisi sebagai inspeksi

Tujuan inpeksi yaitu untuk mendapatkan data atau informasi mengenai pelaksanaan proses belajar mengajar yang dilaksanakan guru. Berdasarkan data tersebut dapat ditentukan tindak lanjut yang akan dilakukan sesuai dengan kebutuhan dan permasalahan guru.

\section{Supervisi sebagai penelitian}

Penelitian bertujuan untuk mengetahui objektivitas dan relevansi data dengan permasalahan yang ditemui pada waktu inspeksi.

4. Supervisi sebagai latihan dan bimbingan

Melalui penelitian dapat ditentukan apa-apa yang harus dilakukan untuk peningkatan dan pembinaan kemampuan guru dalam proses belajar mengajar. Peningkatan kemampuan yang dimiliki guru dilakukan pelatihan dan bimbingan agar lebih efektif.

5. Supervisi sebagai sumber dan pelayanan

Supervisor dapat berperan sebagai sumber informasi, sumber ide, sumber petunjuk dalam berbagai hal dalam rangka peningkatan profesional guru. Supervisor 
juga harus menyediakan waktunya untuk membantu dan melayani guru yang memerlukannya untuk meningkatkan kemampuan yang dimiliki.

6. Supervisi sebagai koordinasi

Kepala sekolah sebagai supervisor harus memimpin sejumlah guru/staf yang mempunyai tugas dan tanggung jawab masing-masing. Agar terlaksana supervisor harus mengkoordinasi atau membina dan memberi bantuan kepada guru/staf.

7. Supervisi sebagai evaluasi

Untuk mengetahui kemampuan guru yang akan dibina perlu dilakukannya evaluasi sehingga program yang diberikan sesuai dengan kebutuhan guru. Selain itu, evaluasi juga dapat menentukan kemampuan guru setelah diberikannya pembinaan dan bantuan atau pun latihan.

Menurut Sabandi (Sabandi, 2013) supervisor memiliki peranan penting dalam meningkatkan mutu pendidik atau guru agar pembelajaran yang terlaksana berkualitas. Jabatan supervisor meliputi kepala sekolah dan pengawas. Supervisi yang dilakukan oleh kepala sekolah telah diatur dalam Permen Diknas Nomor 13 Tahun 2007 tentang standar Kepala Sekolah/Madrasah. Cakupan kompetensi supervisi kepala sekolah meliputi :

1. Merencanakan program supervisi akademik dalam rangka peningkatan profesionalisme guru

2. Melaksanakan supervisi akademik terhadap guru dengan menggunakan pendekatan dan teknik supervisi yang tepat

3. Menindaklanjuti hasil supervisi akademik terhadap guru dalam rangka peningkatan profesionalisme guru.

Supervisi yang dilakukan oleh pengawas diatur dalam Permen Diknas Nomor 12 Tahun 2007 tentang Standar Pengawas Sekolah/Madrasa. Cakupan kompetensi pengawas sekolah/madrasa meliputi :

1. Kompetensi kepribadian

2. Kompetensi supervisi manajerial

3. Kompetensi supervisi akademik

4. Kompetensi evaluasi pendidikan

5. Kompetensi penelitian pengembangan

6. Kompetensional

Berdasarkan dari Permen Diknas Nomor 12 dan 13 Tahun 2007 di atas, bahwa pengawas dan kepala sekolah/madrasah memiliki tanggung jawab dalam meningkatkan profesionalitas guru.

C. Pelaksanaan Supervisi Pendidikan

Pelaksanaan supervisi pendidikan mengikuti beberapa kegiatan, sebagai berikut :

1. Penumpulan data

Proses supervisi diawali dengan pengumpulan data untuk menemukan berbagai kekurangan dan kelemahan guru. Data yang dikumpulkan merupakan keseluruhan situasi belajar mengajar seperti, data siswa, guru, program pengajaran, fasilitas, dan situasi kondisi yang ada. Adapun caranya yaitu observasi, kunjungan kelas, menggunakan kusioner dan sebagainya.

2. Penilaian

Data yang sudah dikumpulkan kemanusiaan diolah untuk dinilai. Penilaian dilakukan terhadap pencapaian siswa, guru, serta faktor-faktor penunjang dan penghambat dalam proses belajar mengajar.

3. Deteksi kelemahan

Pada tahap ini dilakukan deteksi kelemahan atau kekurangan guru dalam proses mengajar. Hal-hal yang harus diperhatikan dalam mendeteksi kelemahan 
guru dalam melaksanakan tugas yaitu, penampilan guru di depan kelas, penguasaan materi, penggunaan metode, hubungan antara personil dan adminitrasi kelas. Kemudian barulah supervisor dan guru memperkirakan kelemahan atau kekurangan yang ada pada guru.

4. Memperbaiki kelemahan

Setelah ditemukannya kelemahan atau kekurangan, maka pada tahap ini dilakukan perbaikan atau peningkatan kemampuan. Memperbaiki kelemahan atau kekurangan dapat dilakukan dengan cara memberikan informasi secara langsung, demonstrasi mengajar, kunjungan, memberikan tugas bacaan, dan memberikan kesempatan mengikuti pelatihan dalam berbagai bentuk.

5. Bimbingan dan pengembangan

Dalam Pelaksanaan supervisi, supervisor perlu memberikan bimbingan kepada guru agar apa yang diperolehnya diterapkan dalam proses belajar mengajar. Bimbingan dan pengembangan ini antara lain dilakukan dengan cara kunjungan kelas, pertemuan pribadi, observasi dan diskusi.

Ada beberapa pendekatan yang digunakan dalam bimbingan yaitu pendekatan humanistik, pendekatan kompetensi, pendekatan klinis, dan pendekatan profesional.

\section{PENUTUP}

\section{Kesimpulan}

Supervisi merupakan pembinaan yang berupa bimbingan kearah perbaikan dalam pendidikan pada umumnya dan peningkatan mutu mengajar dan belajar pada khususnya. Supervisi juga dapat diartikan sebagai pengawasan di bidang pendidikan. Orang yang menjalankan atau yang melakukan supervisi disebut supervisor.

Supervisi memiliki beberapa peranan seperti, supervisi sebagai kepemimpinan, supervisi sebagai inspeksi, supervisi sebagai inspeksi, supervisi sebagai latihan dan bimbingan, supervisi sebagai sumber dan pelayanan, supervisi sebagai koordinasi dan supervisi sebagai evaluasi.

Selain peranan supervisi juga memiliki komponen-komponen dalam pelaksanaannya antara lain, Pengumpulan data, penilaian, deteksi kelemahan, memperbaiki kelemahan, dan bimbingan dan pengembangan. Semua itu dilakukan agar pendidikan di Indonesia memiliki mutu yang tinggi sehingga mencapai kualitas pendidikan nasional.

\section{Saran}

Makalah ini masih jauh dari kata sempurna dan terdapat banyak kesalah, oleh karena itu di harapkan kritik dan saran yang membangun dari pembaca agar makalah ini lebih baik untuk kedepannya.

\section{DAFTAR PUSTAKA}

Hidayat, Maful. 2015. Supervisi Pendidikan. Dikutip dari daymafulhiat.blogspot.com/2015/02/supervisipendidikanpengertiantujua n.html?m=1. (14 Apri). 
Sabandi, A. (2013). Supervisi Pendidikan Untuk Pengembangan Profesionalitas Guru Berkelanjutan. Jurnal Ilmiah Ilmu Pendidikan, XIII(2), 1-9. Retrieved from http://ejournal.unp.ac.id/index.php/pedagogi/article/view/4275

Syahril dan Asmidir. 2009. Profesi Kependidikan. Padang : UNP Press. 